\title{
CYPRESS LANE ESTATE: HUMAN OR MECHANICAL HARVESTING?
}

\author{
Emilio Tedeschi, Sonoma State University, United States
}

We had been primed to be the next world-class wine growing American Viticultural Area (AVA). We had seen Walla Walla, Willamette Valley, and Paso Robles all come into their fame over the last decade. Lake County's history of winemaking predated Prohibition. The soil was volcanic. The entire AVA was elevated above $1000 \mathrm{ft}$, giving us higher quality wine grapes than you would expect. Cypress Lane [Estate] was here to make our smaller Clear Lake AVA number one, and we were going to take the Lake County AVA to the top.

The highest production grape varieties coming out of Lake County were Cabernet Sauvignon and Sauvignon Blanc. Over the last several years, significant plantings had been established throughout the county. Investors and growers were seizing an opportunity made available by skyrocketing grape prices from neighboring Napa, Sonoma, and other AVA's across California. Labor for these vineyards was already an issue five years ago, and it remained an even more urgent issue today. The future of grape growing here was going to require serious innovation to maintain a competitive edge.

-Anthony Decker, director of farming, Cypress Lane Estate, 2018.1

he morning was surprisingly warm for late December as Cypress Lane Estate's Director
of Farming, Anthony Decker, began his vineyard rounds. His responsibilities covered
256 acres of vineyard nestled in various blocks across sprawling hillsides and valley floor. He checked in with his vineyard staff at their stations along the way, asking how they were and whether they were supplied for the day's jobs. At the top of the ridge, Decker stepped out and looked over the valley below. He stood on the newest vineyard project by Cypress Lane

1 All names, dates, and financial and operating data within this case have been disguised at the request of the protagonist and his company.

(C)2019 Emilio Tedeschi

Wine Business Case Research Journal 3 (1) 2019 
Estate (CLE), dubbed "Summit" for its location. Summit was to be the site of 210 acres of Cabernet Sauvignon scheduled for planting in spring 2018. At an elevation of 1,800 ft and comprised of highly prized volcanic soil, Summit would bring 850 tons of Napa Valley quality Cabernet Sauvignon to the wine-grape market for a third of the price.

Decker feared the prospect of labor shortages. With the Summit vineyard effectively doubling CLE's vineyard acreage, it would demand an increase in labor. Vineyards were long term and needed to last at least 30 years. In previous decades there had been seemingly no shortage of skilled labor for California vineyards. However, the availability of an experienced hand-labor workforce was no longer guaranteed due to the Trump administration's crackdown on immigration, wage-labor legislation, and a shrinking labor pool.

Decker embraced mechanization in his farming approach and believed technology was able to overcome any labor issue. With his current vineyard staff of 40 employees, Decker was faced with critical decisions on how to maximize the long-term economic viability of farming CLE's vineyards.

\section{THE LAND}

\section{Lake County}

The AVA of Lake County is in Northern California, bordering Mendocino to its west and neighboring Sonoma and Napa Valley to the south (Exhibit 1). Lake County first produced wine grapes in the late 1870s and developed a reputation across the U.S. for its quality wine grapes throughout the early 1900s.2 Prohibition in the 1930s wiped out the demand for wine grapes in Lake County, and, not surprisingly, farmers turned to other crops. Thirty years passed before a new generation of farmers returned to explore wine grapes. Regardless of the crop produced, Lake County offered rich qualities in terroir largely due to the extinct volcano, Mount Konocti. This dormant volcano provided porous, well-drained soil on its ridgeline, allowing water to collect in Clear Lake and vast underground reservoirs in the surrounding valleys. The landscape visually resembled high desert conditions, but beneath the ground, water was plentiful. Clear Lake itself was so large it produced a natural cooling effect on surrounding valleys, maintaining ideal temperatures for a variety of crops, including wine grapes. The high elevation of Lake County, ranging 1300-2000 ft, reduced disease pressure on crops and further contributed to rapid cooling in the warmer growing months. 3 


\section{Exhibit 1}

Lake County, Sonoma, and Napa AVA's

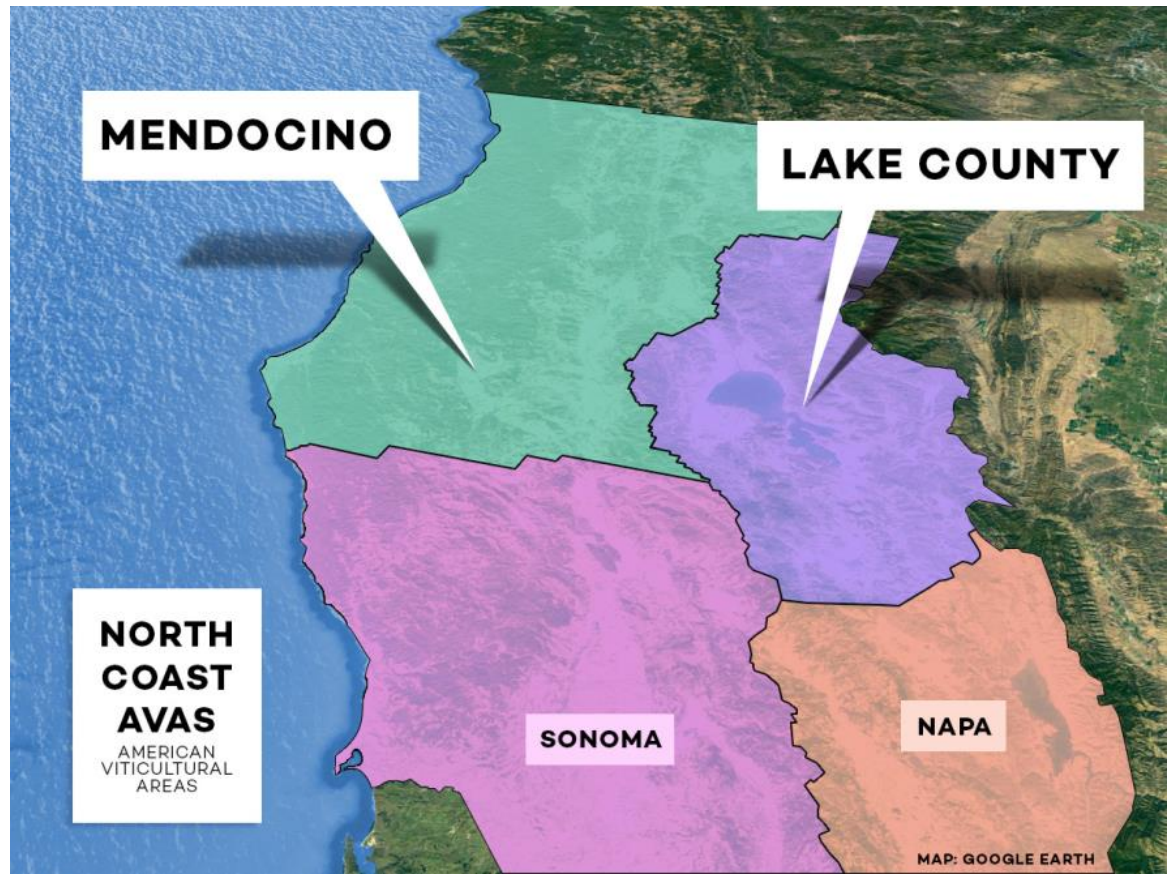

Source: Wine Folly. http://winefolly.com/review/beyond-napa-the-lessor-knownnorth-coast-wine-regions// Retrieved May 3, 2018.

\section{Grape prices}

Despite its long history of grape growing, Lake County was a young AVA in the eyes of wine drinkers. Napa Valley and Sonoma had long dominated the top positions when it came to reputable quality. The marketing efforts of Napa Valley and Sonoma propelled them to stardom, and the world came to expect greatness from these regions. In Lake County, the need for marketing was recognized, and in 1991 the Lake County Winegrape Commission (LCWC) was established. Designed to market Lake County and its sub-appellations, LCWC promoted quality and sustainability as the hallmarks of Lake County winegrowers. From 2007 to 2017, Cabernet Sauvignon grape prices increased in Lake County by an average of six percent per year (Exhibit 2).4 The demand for Cabernet Sauvignon among U.S. consumers had been strong, with growth in off-premise wine sales up five percent from 2016 to 2017.5 Cabernet Sauvignon continued to be the top-selling variety in 2017, as direct-to-consumer (DTC) shipments from U.S wineries saw sales increase by 17 percent from 2016 levels. 6 


\section{Exhibit 2}

Historical Prices for Cabernet Sauvignon,

Lake County vs. Napa County, 2007-2017

\begin{tabular}{ccc}
\hline Vintage & $\begin{array}{c}\text { Average Weighted Price/Ton } \\
\text { Lake County (\$) }\end{array}$ & $\begin{array}{c}\text { Average Weighted Price/Ton } \\
\text { Napa County (\$) }\end{array}$ \\
\hline 2007 & 1,401 & 4,143 \\
\hline 2008 & 1,436 & 4,689 \\
\hline 2009 & 1,404 & 4,619 \\
\hline 2010 & 1,311 & 4,242 \\
\hline 2011 & 1,376 & 4,521 \\
\hline 2012 & 1,612 & 4,999 \\
\hline 2013 & 1,712 & 5,422 \\
\hline 2014 & 1,999 & 5,836 \\
\hline 2015 & 2,143 & 6,240 \\
\hline 2016 & 2,356 & 6,846 \\
\hline 2017 & 2,352 & 7,449 \\
\hline
\end{tabular}

Source: California Department of Food and Agriculture, Grape Crush Reports 2007-2017. https://www.nass.usda.gov/Statistics_by_State/California/Publications/Grape_Crush/Repo rts/. Retrieved March 21, 2018. Figures denoted in USD.

The Alcohol and Tobacco Tax and Trade Bureau (TTB) was established to "collect federal excise taxes on alcohol... and to assure compliance with federal alcohol permitting, labeling, and marketing requirements to protect consumers." 7 Their labeling requirements for wine were imposed to protect consumers from unethical and misleading practices. 8 The TTB mandated that "a viticultural area appellation on the label indicates that 85 percent or more of the wine was produced from wine grapes grown in the named area." 9

What we had been seeing in the industry were grape prices increasing dramatically in Napa Valley and Sonoma. With the blending laws set in place by the TTB, producers in Napa Valley, for example, were able to continue putting "Napa Valley" on their label if 85 percent of the wine grapes used came from Napa Valley. That meant the remaining 15 percent of the wine grapes were able to be sourced from Lake County, which costs a fraction of the price compared to Napa Valley wine grapes.

With prices increasing in their respective counties, winemakers and producers were finding there was a limit on how much cost they could pass on to their end consumers.10 A 2017 panel of top wine industry leaders identified labor prices and labor shortages as major challenges that would make wine-grape farming more expensive in the next decade.11 These leaders also identified increasing demand for premium wine grapes, with no significant new plantings to alleviate the 
issue, as a looming obstacle.12 As a result, the price of wine grapes was expected to increase, leading to margin compression. To relieve financial pressure, some producers found they could improve margins by supplementing their Napa Valley Cabernet Sauvignon with Lake County Cabernet Sauvignon up to the maximum allowable 15 percent. The added benefit, in addition to cost savings, was fruit quality, as Lake County Cabernet Sauvignon was being farmed in conditions similar to Napa Valley's hillside wine grapes. Wine grapes grown in these higher elevations typically delivered much higher quality fruit due to the increased environmental stresses. Napa hillside grapes commanded a premium price compared to wine grapes grown on the valley floor. Together these factors had contributed to the growth of Lake County's grape growing industry, even tracking the price trends of Napa Valley Cabernet Sauvignon. Indeed, Napa County's Cabernet Sauvignon price also increased an average of six percent per year from 2007 to 2017, matching the average year-over-year rate of Lake County (Exhibit 2).13

\section{ANTHONY DECKER}

Anthony Decker was born in Kansas and grew up in Nebraska. He attended the University of Nebraska, where he studied agronomy and horticulture. There Decker was first introduced to grapevines through research he conducted on Pierce's disease, a bacterial infection that affects grapevines. Decker graduated in 2008, in the middle of an economic recession, and had difficulty finding work. By pure chance, he was invited by a colleague to explore winegrowing in a rural region of northern California. Within three months he was surveying land and planning a vineyard in Lake County, with no prior experience in vineyard management.

Despite successfully establishing the vineyard, Decker had disagreements with management, which led him to part ways with this business venture after nearly five years. Soon after, Decker crossed paths with George Whitman, general manager of CLE. Whitman was looking for somebody familiar with Lake County soil, climate, and cultivars to manage their vineyard operations. Not more than a week after his departure from his first vineyard venture, Decker was offered a full-time position at CLE, managing approximately 200 planted acres of vineyard.

\section{CYPRESS LANE ESTATE}

Fred Rockwell purchased the initial Cypress Lane property in 1976, which had been entirely devoted to orchards. Rockwell hired George Whitman, aged 15, as a ranch hand. Whitman eventually worked his way up to general manager, $\mathrm{COO}$, and CFO, taking over the financial operations at CLE. In the early 2000s, Rockwell noticed some neighbors were planting vineyards. He thought vineyards were worth exploring as a revenue source and established the winery shortly thereafter. The first cultivars were planted in 2003, with the original intent to sell most of the wine grapes to other wineries and keep a smaller amount back for CLE wines. As of 2018 , there were 256 vineyard acres producing six different varieties of wine grapes. Andrew 
Bowman was hired as the new winemaker in 2010. As advocates for the Lake County AVA, Decker and Bowman were both actively involved in the Lake County Winery Association, an organization committed to uniting and promoting wineries of Lake County.

Most of the wine grapes from CLE's existing 256 acres were now used to make its estate wines and the rest were sold on the spot market. As a result, there was a lack of available excess wine grapes, namely Cabernet Sauvignon, to sell to clients. Cypress Lane Estate realized it needed more wine grapes to sell in order to meet the expected future demand for Lake County Cabernet Sauvignon. To meet these demands, CLE purchased a neighboring parcel in 2016 (the Summit vineyard) and planted 210 acres of Cabernet Sauvignon. Cypress Lane Estate planned to sell the vast majority of this Cabernet Sauvignon on the grape market. Decker handled negotiating grape purchase contracts and maintaining relationships with wine grape buyers.

During my beginning years in Lake County, I made a point to go to the local wine bar each week where they featured guest tastings. These featured various growers, winemakers, and other wine experts, and, going regularly enough, I quickly found that I knew just about everyone in the Lake County wine industry. When I came to work at Cypress Lane, part of their business model involved selling their excess wine grapes.

I had farmed plenty in Lake County and my previous vineyard was alright, nothing spectacular, but Cypress Lane was the real deal. All of a sudden, I now had a solid network to call people up and say, 'You need to come up here. This is amazing fruit.' With a quality property to farm premium wine grapes, I had all the fruit contracted. Following the market over the years, we knew there was definitely space to be a premium supplier [of Cabernet Sauvignon] in Lake County, and these 210 acres were it.

Key success factors for farming, as indicated by IBISWorld, an independent publisher of industry research reports, included achieving economies of scale, production of premium goods, appropriate physical growing conditions, and availability of irrigation water.14 Cypress Lane Estate grew organically, scaling in stages to control its growth and quality in operations. In doing so, they achieved economies of scale by providing enough work to retain year-round labor crews and implementing machinery into hybrid work crews. Cypress Lane Estate found its land to be fertile, well-drained, temperate in climate, and adequately supplied with water-all ideal conditions for producing premium wine grapes.

\section{OPERATIONS}

Decker joined CLE in 2013 and was promoted to director of farming in 2015. He found the vineyard crews were well trained, loyal to the company, and maintained high standards for their 
work. Decker's staff comprised of two dedicated maintenance personnel, two vineyard managers, tractor operators, irrigators, auxiliary staff, and the vineyard crews (Exhibit 3).

Exhibit 3

\section{Organizational Chart for Cypress Lane Vineyard Operations}

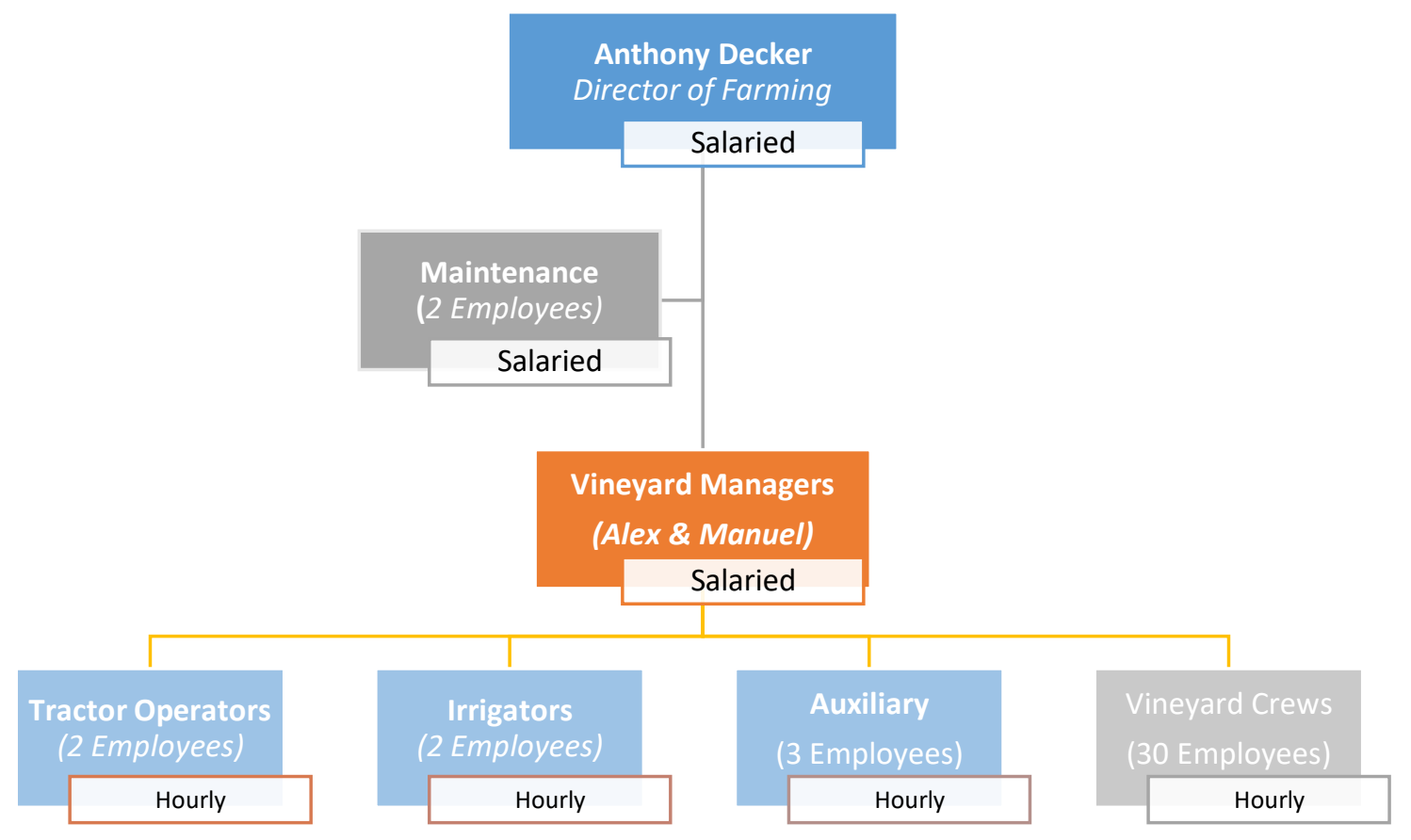

Source: Anthony Decker, Cypress Lane Estate

The tractor operators, irrigators, and auxiliary employees each specialized in their respective departments. However, they were all cross-trained and could perform the job of any other member. This redundancy aimed to help distribute workload throughout the year. During peak periods in the growing season, tasks, such as spraying or hedging, were completed faster because irrigators effectively became on-demand tractor operators. This variable increase in tractor operators in turn allowed for maximum usage of CLE's tractor fleet.

The vineyard crews were used in areas where hand labor was required en masse. These tasks included pruning, canopy management, and harvesting. Decker managed his staff with regularly updated project lists, bi-monthly team vineyard inspections, and weekly meetings. Decker encouraged a high level of autonomy among his vineyard managers. For ongoing projects, he made it a point to ensure consistent communication and open dialogue.

Over the years I had gotten to know each vineyard on the property. I knew which blocks were problematic and which blocks were relatively low maintenance. In terms of labor 
demand, I figured I needed one vineyard employee for every 20 acres. So, for 256 acres, I needed 12 vineyard workers full time. When Summit came into production, we would be at about 470 acres, requiring 24 full-time vineyard workers. We had enough labor now and experienced very low turnover.

When CLE began planting additional acreage throughout the mid-2000s, extra tractors were purchased to offset the costs being incurred by farm labor contractors (FLC), which charged a 50 percent premium for their vineyard services. 15 CLE recognized the need to integrate machinery into its crews. The vineyard staff had since become adept at operating various tractors. To further improve efficiencies, an on-site maintenance shop was the established. Decker's two dedicated maintenance staff was tasked with maintaining the shop, vineyard equipment, and wineproduction machinery. The maintenance staff was cross-trained, experienced, and current in their proficiency with modern-day vineyard equipment. To better ensure the availability of parts, much of the equipment they maintained was from name-brand manufacturers that focused on catering to vineyards. With Decker's full-time maintenance staff, tractors could be easily swapped out in the event of mechanical failures, allowing operations to continue seamlessly. Decker knew the addition of more tractors would be inevitable as Summit came into full production. He did not feel it would be a significant burden on the maintenance staff to add one or two tractors to CLE's existing fleet. All of CLE's equipment was unencumbered with debt.

Based on their years of experience, vineyard managers, Alex and Manuel, understood the work required to hand tend vineyards. Their openness to the benefits of mechanical means in their vineyard operations was crucial. They conveyed to their vineyard staff the advantages of mechanization and allayed the staff's fears that mechanization would lead to job replacement. Both Alex and Manuel had been with CLE for several years. They garnered the respect of the vineyard staff, and CLE recognized their value to the company. In 2017, Alex and Manuel were converted from hourly to salary employees, earning annual compensation of USD 68,000 and 66,000 , respectively. Tractor operators, irrigators, and auxiliary employees were paid hourly rates of USD 18-24, depending on their job function for the day. Vineyard crews were paid an hourly rate of USD 14 .

Cypress Lane Estate considered sustainability essential to farmers and farming. Decker viewed the vineyard staff as the heart of the vineyard operations and their well-being was one of Decker's highest priorities. He knew mechanization reduced physical stresses on hand-labor crews, and its implementation by his design would integrate with crews rather than replace them. Additionally, CLE had long placed an emphasis on environmental stewardship and felt a responsibility to farm with best practices in mind. Cypress Lane Estate had participated regularly in environmental self-assessments made available by the LCWC. They joined more than 70 percent of Lake County wine grape growers who have participated in the Code of Sustainable Winegrape Practices Self-Assessment Workbook.16 This workbook addressed ecological criteria 
with metrics to measure performance in various practices including vineyard water management, pest management, and environmentally preferred purchasing.17 Practices of water conservation had been implemented in both past and ongoing vineyard projects, including dry-farming practices and use of precision irrigation. 18

\section{LABOR ISSUES AND POLITICAL ENVIRONMENT}

Farm labor was important for most agricultural operations, but especially for fruit farms. Some key activities that were able to be performed mechanically for most field crops had to be carried out manually for fruit farms. Thinning, cultivating, harvesting, and sorting had to be done by skilled hand labor to avoid damaging the fragile plants and assuring that the produce met quality standards.19 Farms also hired labor seasonally, especially during peak months when crops had to be harvested.20 Fortunately, CLE had been able to use its economies of scale, and, thereby, retained its entire vineyard staff throughout the year because there was enough work to distribute. Overall, wage costs in the fruit and nut farming industry had increased over the past five years from 19.3 percent of revenue in 2012 to 23.3 percent in 2017.21

\section{Senate Bill No. 3}

California legislation was amended in 2016 when Governor Jerry Brown signed Senate Bill No. 3 (SB 3), effectively setting into law a minimum wage increase of USD one per hour, annually, between 2017 and 2022.22 California minimum wage had been scheduled to increase to USD 15 per hour by 2022 (Exhibit 4). For CLE, planting and maintaining vineyards was capital intensive (Exhibit 5). Their new 210-acre Summit vineyard would need to recoup their initial investment and continue to produce healthy dividends over the long term. The upfront costs of planting were significant, but the primary cost driver was labor. Unlike field crops, vineyards required multiple passes by hand-labor crews throughout the year. Vineyard crews needed to be trained differently, depending on a grower's vineyard and how the cultivars were trained. To remain competitive and retain their workforce, CLE felt pressure to pay a premium over minimum wage. In 2016, wages and salaries accounted for nearly 37 percent of CLE's vineyard operating expenses. Wages and salaries increased to 45 percent the following year (Exhibit 6). Decker felt it was likely CLE's wages would continue to increase each year due to statutory minimum wage hikes.

\section{Assembly Bill No. 1066}

Further legislation introduced new overtime requirements into California law. Assembly Bill No. 1066 (AB 1066), known as the Phase-In Overtime for Agricultural Workers Act of 2016, was passed in late 2016 and went into effect January 1, 2017. Agricultural laborers typically worked 60-hour workweeks, comprised of six 10-hour workdays.23 Overtime was awarded when a shift exceeded 10 hours.24 In addition to mandating a six-day maximum workweek immediately for two years, the bill transitioned agricultural employees, over a four-year period, from working 60 
hours per week to 40 hours per week before becoming eligible for overtime (Exhibit 4).25 This law was intended to transition agricultural workers toward the standard 40-hour workweek, comprised of five eight-hour work days, with overtime awarded after any shift exceeding eight hours.26 Section 862(b) of California Labor Code Section, effective January 1, 2019, allowed for a seventh day to be worked, which had been previously prohibited. For this day employees were to be paid overtime for the first eight hours and double time for any hours in addition. 27

Decker was well aware of these incoming laws. Despite the intended benefits of these laws, Decker surmised it was likely that higher labor costs would move employers to mitigate incurring overtime by readjusting employee schedules.28 Additionally, greater adoption and integration of mechanization was highly likely in the coming years to compensate for volatility in the labor supply.29 


\section{Exhibit 4}

\section{California Minimum Wage, 2017-2022}

\begin{tabular}{|c|c|c|c|c|}
\hline \multirow[b]{2}{*}{ Effective Date } & \multirow{2}{*}{$\begin{array}{c}\text { SB 3 } \\
\text { Minimum Wage }\end{array}$} & \multicolumn{3}{|c|}{ AB 1066} \\
\hline & & $\begin{array}{l}\text { Daily Overtime } \\
\text { Eligibility }(1.5 x)\end{array}$ & $\begin{array}{l}\text { Weekly Overtime } \\
\text { Eligibility }(\mathbf{1 . 5 x})\end{array}$ & $\begin{array}{c}\text { Double Time } \\
\text { Eligibility }(2 x)\end{array}$ \\
\hline January 1, 2017 & $\$ 10.50 /$ hour & $>10$ hours/day & $>60$ hours/wk & \\
\hline January 1,2018 & $\$ 11.00 /$ hour & $>10$ hours/day & $>60$ hours/wk & \\
\hline January 1, 2019 & $\$ 12.00 /$ hour & $>9.5$ hours/day & $>55$ hours/wk & \\
\hline January 1,2020 & $\$ 13.00 /$ hour & $>9.0$ hours/day & $>50$ hours/wk & \\
\hline January 1,2021 & $\$ 14.00 /$ hour & $>8.5$ hours/day & $>45$ hours/wk & \\
\hline January 1, 2022 & $\$ 15.00 /$ hour & $>8.0$ hours/day & $>40$ hours/wk & $>12 \mathrm{hrs} /$ day \\
\hline
\end{tabular}

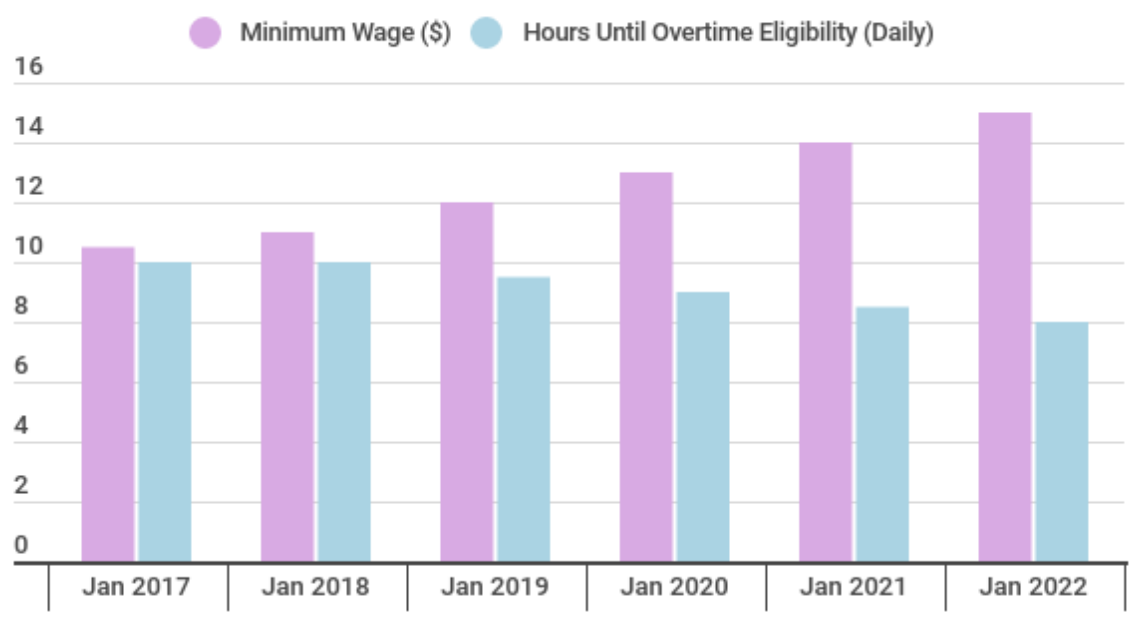

Source: State of California, Department of Industrial Relations. https://www.dir.ca.gov/dlse/SB3_FAQ.htm. Retrieved March 28, 2018. Cortes, D. (2016, July). AB 1066 - Phase-In Overtime for Agricultural Workers Act of 2016 Factsheet, United Farm Workers. http://www.ufw.org. Retrieved March 25, 2018. 


\section{Exhibit 5}

Planting Costs of Summit Vineyard, 2016-2018

\begin{tabular}{|c|c|c|}
\hline \multicolumn{3}{|l|}{ Summit Vineyard* } \\
\hline Project Name & \multicolumn{2}{|l|}{ Cost } \\
\hline \multicolumn{3}{|l|}{2016 - Land Purchase } \\
\hline "Summit" (Adjacent Parcel) - 210 acres & $\$$ & $3,000,000$ \\
\hline \multicolumn{3}{|l|}{ 2016-2017 - Irrigation Pond } \\
\hline Irrigation Pond & $\$$ & $2,049,716$ \\
\hline \multicolumn{3}{|l|}{2017 - Land Preparation } \\
\hline Clearing, ripping, burning, contouring, drainage, avenues & & $1,735,017$ \\
\hline Compost & & 65,071 \\
\hline Permits & & 85,959 \\
\hline Erosion Control & & 15,273 \\
\hline Total Land Preparation & $\$$ & $1,901,320$ \\
\hline \multicolumn{3}{|l|}{2018 - Planting } \\
\hline Cultivars** & & 638,339 \\
\hline Trellis materials, T-post \& fencing, Milk cartons, straw rolls & & 364,554 \\
\hline Irrigation System - drip, filters, boosters station & & $1,900,581$ \\
\hline Total Planting & $\$$ & $2,903,474$ \\
\hline Grand Total & $\$$ & $9,854,510$ \\
\hline *Labor not included & & \\
\hline **Cultivars reserved in nursery, scheduled for planting in 2018 & & \\
\hline
\end{tabular}

Source: Anthony Decker, Cypress Lane Estate. Figures denoted in USD. 


\section{Exhibit 6}

\section{Income Statement for Cypress Lane Vineyard, 2016 and 2017}

\begin{tabular}{|c|c|c|c|c|}
\hline Income Statement & \multicolumn{4}{|c|}{ Cypress Lane Estate } \\
\hline Fiscal Year & \multicolumn{3}{|c|}{2016} & \multirow[t]{2}{*}{2017} \\
\hline REVENUES & & & & \\
\hline Revenue from Grape Sales & $\$$ & $1,825,122$ & $\$$ & $2,322,672$ \\
\hline COGS & $\$$ & - & $\$$ & - \\
\hline Gross Margin & $\$$ & $1,825,122$ & $\$$ & $2,322,672$ \\
\hline \multicolumn{5}{|l|}{ OPERATING EXPENSES } \\
\hline Vineyard & & & & \\
\hline Salaries - Operations & $\$$ & 707,523 & $\$$ & $1,051,762$ \\
\hline Payroll Taxes & $\$$ & 76,812 & $\$$ & 92,675 \\
\hline Health Insurance & $\$$ & 16,330 & $\$$ & 20,351 \\
\hline Repairs/Maintenance & $\$$ & 417,025 & $\$$ & 459,181 \\
\hline Irrigation Supplies & $\$$ & 11,582 & $\$$ & 5,487 \\
\hline Vineyard Supplies & $\$$ & 26,314 & $\$$ & 20,082 \\
\hline Chemicals (Fertilizer, Fungicide, Herb, Pest) & $\$$ & 38,726 & $\$$ & 73,708 \\
\hline Safety Equipment PPE & $\$$ & 1,611 & $\$$ & 3,661 \\
\hline Depreciation & $\$$ & 604,519 & $\$$ & 601,294 \\
\hline Vineyard Expenses & $\$$ & $1,900,442$ & $\$$ & $2,328,201$ \\
\hline Operating Expenses: & $\$$ & $1,900,442$ & $\$$ & $2,328,201$ \\
\hline Net Income from Operations: & $\$$ & $(75,320)$ & $\$$ & $(5,529)$ \\
\hline Earnings before Income Tax: & $\$$ & $(75,320)$ & \$ & $(5,529)$ \\
\hline NET INCOME & $\$$ & $(75,320)$ & $\$$ & $(5,529)$ \\
\hline
\end{tabular}

Source: Anthony Decker, Cypress Lane Estate. Figures denoted in USD.

\section{Political and economic environment}

Since the Dust Bowl of the 1930s, migrant labor, both domestic and foreign, had been the predominant source of harvest labor, especially in California.30 Between declining labor supply and higher wages, finding agricultural labor had become increasingly difficult. Wine industryspecific hiring challenges had come to include: higher competition for an increasingly smaller pool of available and qualified workers, competing industries that pay higher wages, a high cost- 
of-living, inadequate public transportation, scarcity of affordable housing, and increased uncertainty regarding immigration laws.31 The migrant workforce was on edge after the 2016 presidential election, feeling they were constantly being targeted in the news and uncertain about their future. 32

It had been predicted that the wage disparity between the U.S. and Mexico would decrease over the next 20 years. This would result in significant economic consequences for the U.S. agricultural industry, as fewer Mexicans would seek work in the U.S.33 Since 1940, the number of Mexican immigrants coming into the U.S. per year had steadily increased, but reached a peak in 2010, according to the Migration Policy Institute.34 Labor statistics indicated a steady decline of the immigrant labor pool from Mexico over the past 10 years.35 The increase in California minimum wage had been predicted to drive all wages higher as companies were forced to raise salaries to remain competitive.36 Market forces, such as inflation and competition from cannabis, hospitality, and other industries, for labor were expected to push all salaries higher.37 In the long term, wineries realized the need to revisit the economics of mechanization, outsourcing labor, and educating and training their workforces. 38

The recession of 2007-2009 sent federal interest rates to historic lows. The Federal Reserve had begun raising interest rates and had scheduled future rate hikes in 2018.39 These lower rates favored financing options for businesses, particularly if they had locked in fixed rates based on the current economy.40 For growers, this meant capital intensive investments, such as equipment, infrastructure, and expansion, were more readily within reach. 41

\section{MACHINERY}

Greater adoption and integration of mechanization was expected to compensate for volatility in labor supply.42 In a 2006 survey, 85 percent of large growers (over 500 acres) were already using machines.43 Many tasks in CLE's vineyard were being performed by machines, including plowing, spraying, and hedging. But some tasks, such as pruning and harvesting, almost exclusively used hand labor due to the required human judgment and steeper vineyard terrain. Decker knew that harvest was the most critical and costly period of the year. Harvest required the largest peak demands of labor across the ranch, and he knew that if progress was to be made in curbing operational overhead, harvest was the piece to tackle.

In the early 1960s, farmers had begun experimenting with mechanical harvesting of wine grapes.44 These first harvesters simply knocked the wine grapes off the vines while punishing the cultivars and trellis systems. Consequently, results were poor, and mechanical harvesting languished in the U.S.45 In the 1970s France, Australia, and later, the U.S. imported mechanical 
technology to mitigate grape farming labor shortages.46 By this point, mechanical harvesters had evolved dramatically and offered numerous advantages over their human counterparts.

Self-propelled and tow-behind mechanical harvesters had been the most used in the grape industry. The tow-behind harvester typically cost half the price of self-propelled models.47 These harvesters had evolved to become more versatile over the years, allowing for the integration of pruning and spraying attachments. Mechanical harvesters, such as those manufactured by Pellenc, now carried onboard de-stemmers and sorters, operations which were typically reserved for production staff at wineries.48 These features ultimately translated into a lower operating cost per acre. 49

All new vineyards needed to be set up for machinery, even if it was not the best setup for the cultivars, simply out of necessity. I was looking at purchasing two tow-behind Pellenc mechanical harvesters at USD 215,000 each. I was paying vineyard crews to hand pick at USD 140 per ton, and that would probably increase a little every year. But a Pellenc only requires one operator, at USD 20 per hour, and they would harvest 1.5 acres per hour. If I have four tons per acre in full production, the cost savings could pencil out for the Summit vineyard.

Mechanical harvesters offered the benefits of speed, reduced operational costs, flexible picking schedules, zero fatigue, and the ability to move large quantities of wine grapes efficiently. Growers could respond quickly to a heat spell or incoming storm.50 Many growers had difficulty anticipating labor because the wine grapes need to be picked at a certain sugar content. If they stopped for a few days, they lost their entire crew. The ability to move large amounts of wine grapes quickly made it possible to deliver a predictable flow of wine grapes, making it easier for the winemaker to schedule people and ease the demands on the winery production staff.51 Night harvesting was highly desirable, as wine grapes picked at evening temperatures greatly reduced issues, such as oxidation and microbial spoilage. 52

Wine producers at a 2013 industry roundtable discussion noted that machine harvesters had evolved considerably in just the past decade alone. 53 The advancements in achieving gentler and more precise grape harvests resulted in increased efficiencies related to optimized harvest dates, increased rates of harvest, and more efficient distribution of human and machine resources to maximize harvest operations.54 A winery no longer needed an expensive stemmer/crusher. Instead, they could reallocate all the labor and cost normally attributed to setup, breakdown, and operation of the crusher to more urgent cellar work, such as sanitation, punch downs, and wine testing.

The quality of the wine grapes had been found to be very comparable between hand harvesting and machine harvesting, with tradeoffs occurring in the field.55 Decker himself had sold wine 
grapes to clients in the past who were adamant about their wine grapes being hand harvested. In wine regions, such as neighboring Sonoma and Napa Valley, it was not uncommon for wineries to resist machine harvesters, instead requiring that their contracted growers harvest by hand.56 Some years later, inclement weather or timing constraints would force Decker to harvest his clients' wine grapes by machine. After the clients saw firsthand the promptness in delivery and quality of wine grapes picked by Decker's machine harvesters, they stopped requesting hand harvesting and opted for machine harvesting every year thereafter. For long-time clients, Decker would sometimes pass on his savings, in some instances discounting as much as USD 200 from the tonnage price for machine-harvested wine grapes.57 A number of producers had determined that machine-harvested wine grapes delivered a similar level of quality to hand-harvested wine grapes with significant cost savings, allowing for a redistribution of the resources needed to make their products. 58

A drawback of mechanical harvesters was that they needed to be used on mature cultivars. Decker felt comfortable using Pellenc harvesters on cultivars beginning in their fifth year.59 Anything younger lacked adequate root strength and therefore ran the risk of being uprooted during mechanical harvest. Decker would need to harvest these younger cultivars in their third and fourth years by hand. When it came to the quality of wine grapes handpicked compared to machine picked, Decker felt the difference to be minor. He felt that the cost benefits of machine harvesting could outweigh the downside of potential difference in harvest quality.60

\section{LOOKING FORWARD}

Decker stood on the Summit, overlooking the neatly arranged vineyard posts staked below. He and his crew would be planting a newly grown Cabernet Sauvignon cultivar at the base of each stake in a few short months. Decker reflected on his time in Lake County. Farm labor, which was virtually guaranteed 10 years ago, might exist only as a shadow of itself in another 10 years. This vineyard was in its infancy, yet it would continue its production for nearly three decades. The vineyard industry and CLE were at a turning point. Labor costs and volatility were expected to increase. Farming costs would increase. As an agricultural operation, Decker recognized harvest as the most demanding period of the season. On the Summit vineyard alone, 850 tons of premium hillside wine grapes would need to be harvested annually. To ensure the long-term viability of his vineyards, Decker knew the solution started with containing harvest costs. There was an important decision to be made in the near term: should CLE continue hand harvesting or apply mechanical harvesting? The vineyard crews were loyal to the company, they displayed good judgment in quality when hand harvesting, and they performed quality work. But with rising costs of living and increasing wages each year, it was difficult to say with certainty how many of the vineyard staff would be here in the next five years. Mechanical harvesters were 
expensive up front, yet the annual operating costs remained relatively fixed, and the maintenance shop would have the capacity to maintain them.

Decker was proud of what his team had accomplished. He was determined to find the solution; it had to be both sustainable and profitable for CLE. As Decker continued his vineyard rounds, he was confident that he and his vineyard staff would find the right solution for labor during harvest season. 


\section{Endnotes}

1 All quotes in this case, except where noted, are based on field interviews with Anthony Decker in 2018. 2 Lake County Winegrape Commission. (n.d.). Retrieved March 27, 2018, from https://www.lakecountywinegrape.org/

3 Ibid.

${ }_{4}$ Grape Crush Report Final 2007-2017. (n.d.). Retrieved March 15, 2018, from https://www.nass.usda.gov/ 5 Cabernet Sauvignon Reigns as King. (2017). Wines \& Vines, 31-33.

6 Ibid.

7 Alfd. (n.d.). Wine Labeling. Retrieved March 25, 2018, from https://www.ttb.gov/wine/wine-labeling.shtml 8 Mendelson, R. (2011). Wine in America law and policy. New York: Wolters Kluwer Law \& Business.

9 Alfd. (n.d.). Wine Labeling. Retrieved March 25, 2018, from https://www.ttb.gov/wine/wine-labeling.shtml 10 Goldfarb, A. (2017, May 1). Vineyard Lending Outlook. Wine Business Monthly, 66-70.

11 Smiley, R., \& Simmons, N. (January 2017). Industry Leaders Optimistic About Premium Wines. Wines \& Vines, 150-160.

12 Ibid.

13 Grape Crush Report Final 2007-2017. (n.d.). Retrieved March 15, 2018, from https://www.nass.usda.gov/ 14 Masters, N. (2017, October). Fruit \& Nut Farming in the US (Rep. No. 11135). Retrieved March 28, 2018, from IBISWorld website: https://clients1.ibisworld.com/reports/us/industry/default.aspx?entid=25

15 Anthony Decker [Personal interview]. (2018).

16 Lake County Winegrape Commission. (n.d.). Retrieved March 27, 2018, from https://www.lakecountywinegrape.org/

17 Aguirre, J. (2012). California code of sustainable winegrowing workbook [3rd Edition]. Retrieved March 19, 2019, from https://www.sustainablewinegrowing.org/swpworkbook.php

18 Anthony Decker [Personal interview]. (2018). 
19 Masters, N. (2017, October). Fruit \& Nut Farming in the US (Rep. No. 11135). Retrieved March 28, 2018, from IBISWorld website: https://clients1.ibisworld.com/reports/us/industry/default.aspx?entid=25

20 Ibid.

21 Ibid.

22 Labor Standards Enforcement. (n.d.). New Minimum Wage Phase in Requirement 2017-2023 SB 3 Frequently Asked Questions. Retrieved March 25, 2018, from https://www.dir.ca.gov/dlse/SB3_FAQ.htm

23 Anthony Decker [Personal interview]. (2018).

24 Ibid.

25 Cortes, D. (2016, July). AB 1066 Phase-In Overtime for Agricultural Workers Act of 2016. Retrieved March 25, 2018, from https://ufw.org/pdf/AB1066FarmworkerOTFactSheetFINAL.pdf

26 Ibid.

27 Smiley, R., \& Simmons, N. (January 2017). Industry Leaders Optimistic About Premium Wines. Wines \& Vines, 150-160.

28 Anthony Decker [Personal interview]. (2018).

29 Anthony Decker [Personal interview]. (2018); Masters, N. (2017, October). Fruit \& Nut Farming in the US (Rep. No. 11135). Retrieved March 28, 2018, from IBISWorld website: https://clients1.ibisworld.com/reports/us/industry/default.aspx?entid=25

30 Pregler, B. (2006, November). Product Review: The New Wave of Mechanical Harvesters. Wine Business Monthly. Retrieved March 28, 2018, from https://www.winebusiness.com/wbm/?go=getArticleSignIn\&dataId=46289

31 Alary, K., \& Higueras, L. (2017, October 1). Survey Indicates Challenges for Employers Hiring Qualified Workers Continues. Wine Business Monthly, 72-74.

32 Kirschenmann, E. (2017, August 1). Labor. The Writing on the Wall: What to Know When Budgeting Labor Costs. Wine Business Monthly, 26-31.

33 Ibid.

34 Alary, K., \& Higueras, L. (2017, October 1). Survey Indicates Challenges for Employers Hiring Qualified Workers Continues. Wine Business Monthly, 72-74.

35 Ibid.

36 Ibid.

37 Ibid. 
38 Ibid.

39 Irwin, N. (2018, March 9). US economy is looking awfully strong: Report. North Bay Business Journal. Retrieved March 29, 2018, from https://www.northbaybusinessjournal.com/industrynews/employment/8095460-181/useconomy-humming

40 Smiley, R., \& Simmons, N. (January 2017). Industry Leaders Optimistic About Premium Wines. Wines \& Vines, 150-160; Masters, N. (2017, October). Fruit \& Nut Farming in the US (Rep. No. 11135). Retrieved March 28, 2018, from IBISWorld website: https://clients1.ibisworld.com/reports/us/industry/default.aspx?entid=25

41 Smiley, R., \& Simmons, N. (January 2017). Industry Leaders Optimistic About Premium Wines. Wines \& Vines, 150-160; Quackenbush, J. (2017, December 25). California North Coast wine M\&A slows in 2017 amid smaller crop. North Bay Business Journal. Retrieved March 29, 2018, from http://www.northbaybusinessjournal.com/northbay/sonomacounty/7752364-181/sonoma-napa-wine-mergersacquistition

42 Anthony Decker [Personal interview]. (2018); Masters, N. (2017, October). Fruit \& Nut Farming in the US (Rep. No. 11135). Retrieved March 28, 2018, from IBISWorld website: https://clients1.ibisworld.com/reports/us/industry/default.aspx?entid=25

43 Pregler, B. (2006, November). Product Review: The New Wave of Mechanical Harvesters. Wine Business Monthly. Retrieved March 28, 2018, from

https://www.winebusiness.com/wbm/?go=getArticleSignIn\&dataId=46289

44 Ibid.

45 Ibid.

46 Ibid

47 Anthony Decker [Personal interview]. (2018).

48 Pellenc S.A.S. (n.d.). Retrieved March 29, 2018, from http://www.pellenc.com/

49 Pregler, B. (2006, November). Product Review: The New Wave of Mechanical Harvesters. Wine Business Monthly. Retrieved March 28, 2018, from https://www.winebusiness.com/wbm/?go=getArticleSignIn\&dataId=46289

50 Ibid.

51 Mendelson, R. (2011). Wine in America law and policy. New York: Wolters Kluwer Law \& Business.; Pregler, B. (2006, November). Product Review: The New Wave of Mechanical Harvesters. Wine Business Monthly. Retrieved March 28, 2018, from https://www.winebusiness.com/wbm/?go=getArticleSignIn\&dataId=46289

52 Ibid.

53 Cutler, L. (2013, October). Industry Roundtable: Mechanical Harvesting. Wine Business Monthly. Retrieved February 18, 2019, from https://www.winebusiness.com/wbm/index.cfm?go=getArticle\&dataId=121860 
54 Ibid.

55 Ibid.

56 Goldfarb, A. (2008). Moving Toward Mechanical: High-end winemakers warm slowly to machine harvesting. Wines \& Vines. Retrieved February 18, 2019, from

https://winesvinesanalytics.com/features/article/53452

57 Anthony Decker [Personal interview]. (2018).

${ }_{58}$ Cutler, L. (2013, October). Industry Roundtable: Mechanical Harvesting. Wine Business Monthly. Retrieved February 18, 2019, from https://www.winebusiness.com/wbm/index.cfm?go=getArticle\&dataId=121860

59 Anthony Decker [Personal interview]. (2018).

60 Ibid. 